\title{
DEVELOPING AN ENTREPRENEURIAL MINDSET IN ENGINEERING STUDENTS
}

\author{
Amy Hsiao \\ Memorial University of Newfoundland \\ amy.hsiao@mun.ca
}

\begin{abstract}
Developing engineers with entrepreneurial skills is becoming a valued objective for engineering faculties across the country. Entrepreneurship courses are being added to engineering curriculum, course options are being created to allow students to pursue an entrepreneurship or management track in their undergraduate engineering studies, and graduate programs are being developed in Engineering Management, as a more specific and alternative route to the Master of Business Administration (MBA). This paper presents the results of a six-year survey of engineering students who have elected to enroll in an upperclassmen Entrepreneurship course. It presents the approach that has been taken in an Engineering elective at Memorial University to develop entrepreneurially minded engineering students, and the students' perspectives on why engineers become entrepreneurs, what entrepreneurial qualities they believe they possess, and how they have learned to evaluate entrepreneurial ideas not only on its technical merit, but organizationally and strategically.
\end{abstract}

Keywords: technology, innovation, entrepreneurship, management, invention, new ventures

\section{BACKGROUND}

Introduction and experience in entrepreneurship at the undergraduate level is beginning to be perceived as having an important role in the type of engineering students that universities graduate and the type of engineering education these students receive. According to the Canadian Engineering Accreditation Board (CEAB) of Engineers Canada, engineering institutions must demonstrate that the graduates of their program possess attributes such as: (1) use of engineering tools, (2) individual and team work, (3) communication skills, (4) professionalism, (5) impact of engineering on society and the environment, (6) ethics and equity, (7) economics and project management, and (8) life-long learning [1]. These attributes, if not all of them outlined by the CEAB, are significantly supported by exposure to, and experience in, engineering entrepreneurship.

The course "Business Planning and Strategy in an Entrepreneurial Environment", colloquially referred to as "Engineering Entrepreneurship", is a Term 8 elective that introduces engineering students from all disciplines to the concepts, issues, and themes related to business planning, strategy, and entrepreneurship. The course provides an overview of the functional activities in a typical business venture, such as organizational behavior, human resources, finance, marketing, and operations. It explores the business planning and strategic management issues of technology-driven enterprises in the early stages of development, and analytical business skills are developed in this course.

The course focuses on the "engineer as entrepreneur" by encouraging students to combine and apply their creativity and technical skills to develop a business strategy for a technology-based idea. Through class discussions on selected case studies, lectures, and dialogue with local entrepreneurs as invited guest speakers, students are exposed to a spectrum of corporate activities in the entrepreneurial environment. Students are also encouraged to assess their potential for entrepreneurial careers and develop attitudes and skills that will be useful in engineering new ventures.

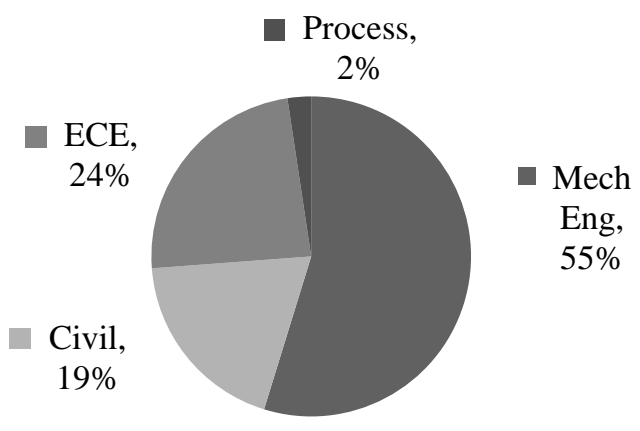

Fig. 1. Percentage of disciplines represented in Engineering Entrepreneurship

Two-hundred and twenty-five (225) profiles were collected from engineering students enrolled in 
"Engineering Entrepreneurship" over a period of six (6) years, starting in 2008 and continuing to 2013. As shown in Figure 1, the majority of students have been Mechanical Engineering students, with Civil, Electrical and Computer, Process Engineering students represented as well.

\section{AN ENTREPRENEURIAL MINDSET}

The course structure is divided into two major components, one on defining what an entrepreneurial opportunity is and learning how to identify "opportunities", and two on the internal components of an engineering-based new venture, i.e. the entrepreneurial team, start-up funding and finance, marketing, new venture growth, and exit strategies. Students learn these concepts through lectures, textbook reading, class discussions of video cases from "CBC's Dragon Den", "60 Minutes," "NPR podcasts", and other media forms. Local and international entrepreneurs are invited as guest lecturers to the class, and these speakers add their experience to the knowledge that is gained through classroom learning.

\subsection{Identifying Opportunities}

Engineering students are asked to define and identify "opportunities"; not only in the sense of a potential invention, but how well the invention would be a product or service, i.e. if there is a "window of opportunity" and what market there exists for it. In specific, understanding trends in the marketplace, determining characteristics of different industries, and learning about disruptive and incremental technological transitions, provide students with the conceptual basis for defining what an entrepreneurial opportunity is, as shown in Figure 2.

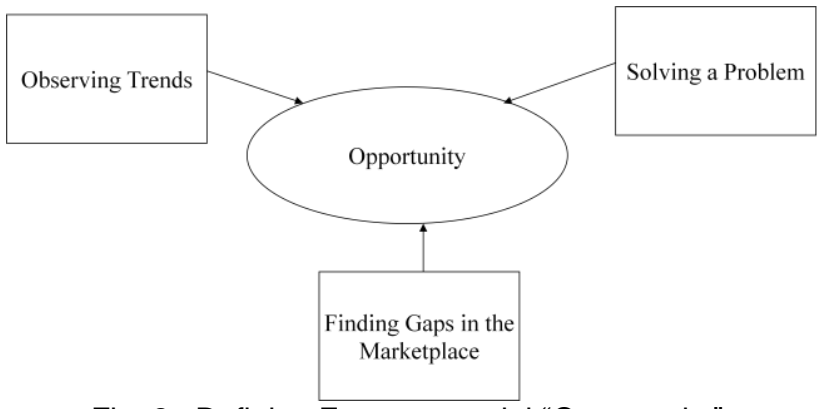

Fig. 2: Defining Entrepreneurial "Opportunity"

Opportunity gaps are assessed by considering the political, economic, technological, environmental, legal/regulatory, and social/demographic factors that contribute to current trends in consumer demand, lifestyle preferences, and market conditions; these are considered external factors that would signal to an entrepreneur that a potentially viable opportunity might be viable, as shown in Fig. 3.

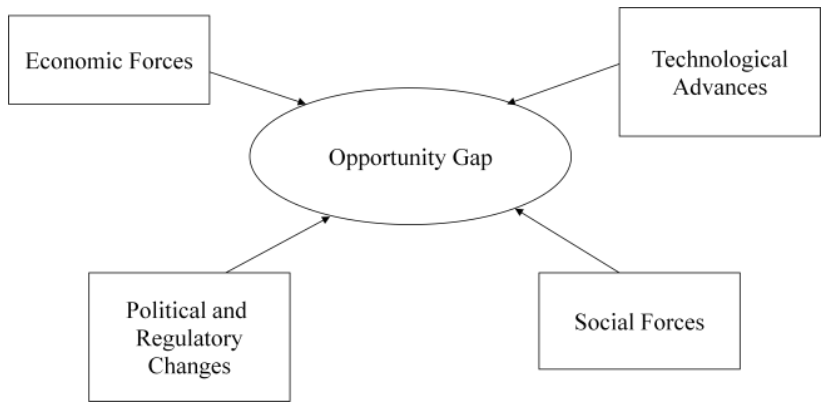

Fig. 3: Defining “Opportunity Gap”

In the past 6 years, the class has focused on the current "hot trends" of that period, which have included an increase in social networking, a do-it-yourself mentality (due to weakening economies), an aging population that is living longer, and a green/environmentally-conscious perspective, for example. As a result, the development of the smartphone market, online group buying (e.g. TeamBuy, Groupon, LivingSocial), and even Facebook, have been studied as "entrepreneurial opportunities".

\subsection{Understanding Marketing}

Marketing is an area that is entirely unique, in terms of its approach, for engineering students. It is the period in the class that students start with thinking about their associations, reactions, and feelings with the technologybased products and services they value. In understanding marketing, the ideas of "value added" and "customer relationship" are introduced, stressing that for new ventures to be successful in their respective markets, there should be an effective effort to attractively pull potential customers towards their products or services. In this respect, the course presents ten different marketing assignments that enable students to explore aspects of the marketing mix (e.g. price, product, place, and promotion), how to build and sustain customer relationships, and what makes effective marketing:

- $\quad$ Product branding

- Use of advertising

- Product-market segmentation

- Brand meaning

- Marketing to different demographics

- Recovering lost customers

- $\quad$ Service marketing

- Non-traditional marketing

- Business-to-business marketing

An example of an assignment in one of these categories is shown: 
Non-traditional marketing strategies can be really useful for technology-based new ventures starting out with very little budget to spend on promotion. We discussed in class several different types of promotion - from print ads to commercials and flyers - which are traditional methods, and non-traditional methods such as using social networking, "free" media, word-ofmouth (viral) marketing, and creativity (guerilla) marketing. Consider the example of RIM and other examples of non-traditional marketing that you think have been effective in building brand meaning for customers and a sense of $a$ relationship with customers.

In your presentation, describe all components of the ice cream cone of marketing as it applies to the examples you've chosen. How did the companies build brand meaning? It is inherent that the 4P's would be part of this discussion. Why do you think the companies you've chosen would use non-traditional media for its marketing? How do you see this applied to a new, "quirky" technology product or service? Explain, describe, and show to the class in your presentation.

The "ice cream cone" of marketing that is referenced was proposed by Dr. Jim Barnes [2] as a novel way of moving from "customer strategy" to "customer relationships", using customer data to know more than their spending habits but to understand their lifestyles and the value that customers feel that technology products or services add to their lives.

\subsection{Conducting Business Feasibility}

The third aspect used in developing an entrepreneurial mindset in engineering students is application of what is learned in "identifying opportunities" and marketing. Students engage in a semester-long, team-based project in which they research the business feasibility of an opportunity they have identified and present it in the form a preliminary business plan for a new venture. As such, students analyze secondary research on industry, market, competition, and work together to determine what the core competence of their new venture will be and how their product or service will be uniquely differentiated. Fig. 4 shows the different components of a standard business model, and viability is emphasized as the functioning interrelation between infrastructure of the new firm, value proposition, customer relationship, and in-out flow and expenditure of cash.

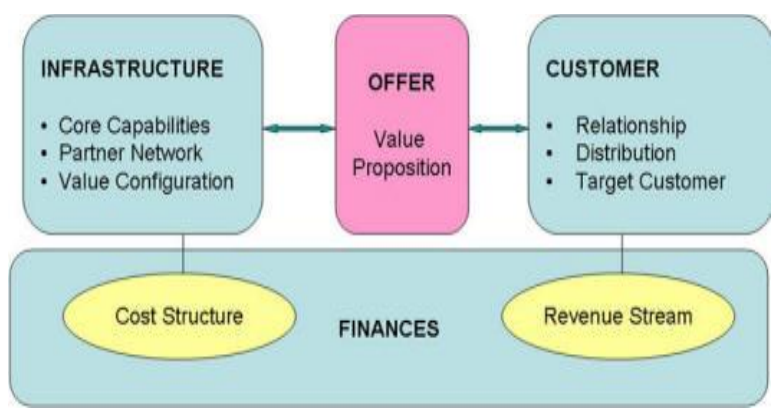

Fig. 4. New venture business model

The new venture ideas that have been generated in the Engineering Entrepreneurship course over the six-year period can be categorized according to Ansoff's Marketing Matrix, as shown in Fig. 5 [3]. The product development and market development strategies presented the most opportunities for new ventures for the students in the course, with some students identifying a new business idea using a diversification strategy, as shown in Tables 1-3.

\begin{tabular}{|l|l|l|}
\hline & Present Products & New Products \\
\hline $\begin{array}{l}\text { Present } \\
\text { Markets }\end{array}$ & Market & Product \\
& $\begin{array}{l}\text { Present } \\
\text { product/service in } \\
\text { present market }\end{array}$ & $\begin{array}{l}\text { Development: } \\
\text { new } \\
\text { product/service in } \\
\text { present market }\end{array}$ \\
\hline $\begin{array}{l}\text { New } \\
\text { Markets }\end{array}$ & Market & $\begin{array}{l}\text { Diversification: } \\
\text { new } \\
\end{array}$ \\
& $\begin{array}{l}\text { present } \\
\text { product/service in } \\
\text { new market }\end{array}$ & $\begin{array}{l}\text { product/service in } \\
\text { new market }\end{array}$ \\
\hline
\end{tabular}

Fig. 4. The product-market growth matrix for identifying entrepreneurial opportunities in innovation. [3]

Table 1: New Venture Ideas Using Product Development Strategy

- Small-scale, hydro-based energy generator

- Small-scale, automated indoor/outdoor environment

- Aquarium canopy for fish tanks

- $\quad$ Bluetooth technology to track people during evacuation or emergency

- Cursor manipulation via eye movement

- Decision-based video game software development

- Cell phone integrator for video game controllers

- Interactive guitar learning software

- Home energy monitoring system

- Dine-in movie theatre

- Day spa for men's grooming and well-being

- Grocery list-vendor/store app

- $\quad$ Emergency information and response app

- Chicken manure pellet fertilizer

- Headlight for recreational vehicles 
Table 2: New Venture Ideas Using Market Development Strategy

- Wireless broadband Internet service for downtown St. John's

- $\quad$ Service to provide assistance and set-up of electronic devices for end users in St. John's

- Heavy metal radio station in St. John's

- "Green" construction waste management in Newfoundland and Labrador

- Two-in-one used car dealership/body shop in NL

- Bread slicer for medium-sized bakeries and homeowners

- Online TV/video service focusing on niche Canadian cable channels

- Touch-screen drive-through ordering

- Grocery/meals home-delivery in St. John's

- Vending machine for smoothies

- George Street pub crawl

- Downtown daily shuttle from outskirt communities

- Laundry service for university students

Table 3: New Venture Ideas Using a Diversification Strategy

- Database for linking "word-of-mouth" service providers with customers (childcare, house-sitters, maid service, plumbers, etc.)

- $\quad$ Electronic touch screen for point-of-sale ordering in sports bars

- Home energy audits

- Daily social network bar/pub/restaurant deals app

\subsection{Using Management Tools}

The course also introduces the concept of $360^{\circ}$ feedback used in technology start-ups and teamwork to encourage engineering students to analyze their classmates' new venture ideas and associated business plan strategy. This horizontal feedback allows constructive peer input in a non-threatening way that prepares students for future interactions with investors, incubation opportunities, and entrepreneurial networks. In particular, the use of $360^{\circ}$ peer feedback is focused on the evaluation of "creating and capturing value for customers" and answering the question of "is there a market, let alone demand, for this product or service" that moves away from the "we will build it and they, e.g. customers, will come" mentality of inventors. In this manner, students were asked to evaluate their classmates' elevator pitches presented in class in the following manner via anonymous feedback survey that was filled out "real-time" using an online survey tool:

- Comment on the group's business idea.

- Comment on the selected industry for this idea.

- What other industries should they explore?
- Comment on the idea's target customer base?

- What other demographics or customer segments should be considered?

- Will the concept/usability testing proposed give useful information about the customers and markets to whom the idea is aimed?

- Do you think this idea is feasible at this point? If not, what else should be considered to make it more feasible?

- The elevator pitch was delivered with creativity and preparedness. (Scale of 1 to 5)

- All team members participated in a positive and organized manner in the elevator pitch. (Scale of 1 to 5$)$

- The business idea was explained clearly. (Scale of 1 to 5 )

Engineers are comfortable and understand the process of new product development, whether it is an incremental change or introducing a disruptive technology, as this is what "innovating" means for engineers. However, when engineers use the "inventor" perspective only, there is a failure to understand what it means to create and capture value for customers and to create a business model, i.e. the other important facet of innovation that entrepreneurs tend to grasp better. The $360^{\circ}$ peer feedback gives students the opportunity to sit in the "investor's seat" as well as understand the work required to assess the business feasibility of a new venture.

\section{DISCUSSION}

The reasons for why students chose to register for this elective have continued to be a great starting point of class discussion during the first week of class. The enrolled students are really a "captive audience", in that they are fully interested in learning about engineering entrepreneurship, being inspired, and taking advantage of a topic different from their usual engineering program (but achieving the graduate attributes defined by the CEAB). As shown in Figure 5, the majority of the students indicated that they selected the Engineering Entrepreneurship course because:

- They have thought about starting a business

- They are interested in learning how to start a business successfully

- They do not have enough exposure in the curriculum in entrepreneurship

Other reasons included (1) they selected the course for inspiration, (2) they were thinking of pursuing an MBA after graduation, (3) they had been exposed to start-ups on work-terms, (4) they are interested in project management, (5) they have family who own their own businesses, and (6) they are interested in a managerial role in the future. 


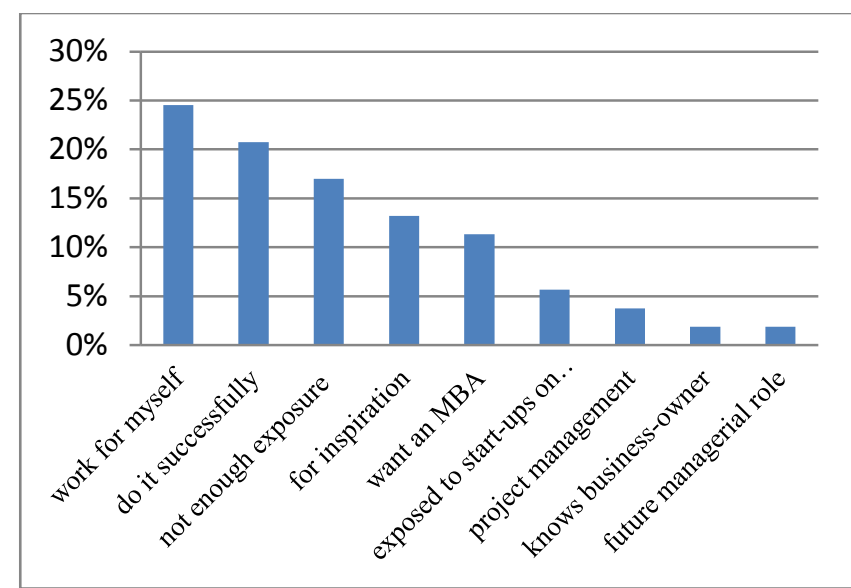

Fig. 5. Response to why engineering students are interested in Engineering Entrepreneurship, percent (\%) response vs. reason

As shown in Figure 6, the responses to what "entrepreneurship" means were specific to five different definitions:

- Pursuing ideas into businesses

- Assuming risk to start a business

- Bringing together resources to create a viable business

- Moving an idea to profit, under one's own direction

- Identifying a need and the idea to address that need

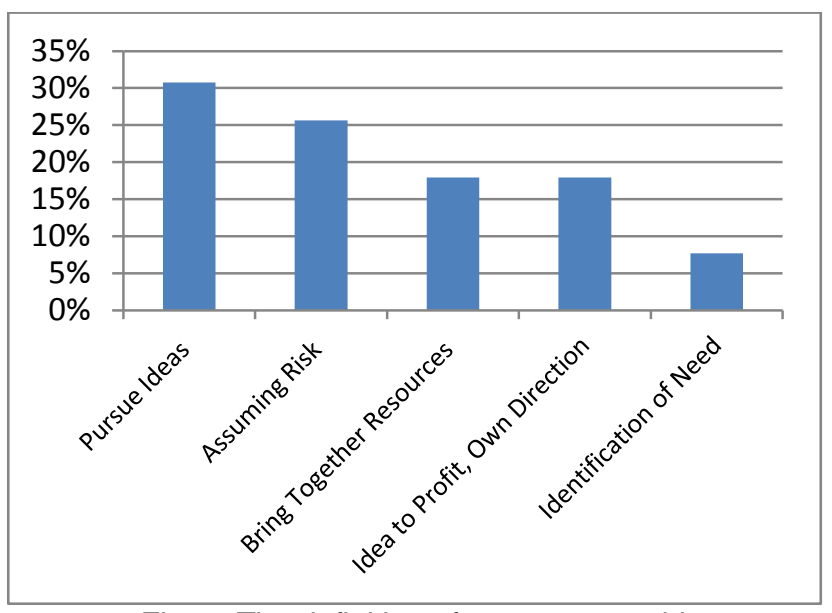

Fig. 6. The definition of entrepreneurship.

\subsection{Tangible Outcomes}

Engineering students in this course expand the phrase "thinking outside the box" to what it means for an entrepreneur. Making the unusual connections for the engineering student interested in launching a new venture requires the consideration of people, organization, and management skills, not only the adept use of technical, analytical skills. As in the qualitative responses to the questions posed in Table 2, directing students to think "outside of the engineering feasibility box" of a given business idea, towards business feasibility is the desired outcome. The transition from the technical disciplines to entrepreneurship involves a bridging of two types of knowledge. The engineer who cannot think entrepreneurially will find it challenging to apply business tools required to make a technology into a commercial product. In the six years of this course, nine out of the 225 graduates have started their own ventures, become one of the founding members of a new venture organization, or won business plan competitions for their ideas. These graduates have also returned as guest speakers in the course to share their experiences.

\subsection{Intangible Outcomes}

The course has also presented the opportunity to "teach" students about networking and leadership, skills that are often subtle and unable to be defined. Through interaction, and observation of, the entrepreneurs who are invited as guest speakers and who are presented in video clips, students learn the intangible qualities of gratitude, perseverance, and practicality that are often demonstrated by entrepreneurs. Engineering entrepreneurs tend to have a strong internal locus of control, which means that they believe they are in charge of their destiny and therefore tend to take responsibility for their successes and their failures, rather than attributing them to external reasons [4]. While this can be a positive trait, the negative side is that a well-connected strategic support network could enhance a new venture's market position, help to defend against competitors, and enable the start-up to secure a competitive product-market strategy. Despite the apparent benefits associated with establishing a good strategic support network, it is common for entrepreneurs to "go it alone", often learning by trial and error and making little use of government and industrial support networks [5]. The lack of access to these networks leaves entrepreneurs unaware of their existence or their benefits [6]. The only exception is entrepreneurs that spin out of entrepreneurial universities [7].

As shown in Fig. 7, Engineering Entrepreneurship students believe that their primary entrepreneurial quality is being "creative or innovative" and their secondary entrepreneurial quality is "a good work ethic." Qualities such as having charisma and integrity, and being energetic, confident, optimistic, disciplined, goaloriented, decisive, observant, and responsible were mentioned but insignificant in the results. Classroom discussion on the results from Fig. 7 have centred on the importance of team skills, and professional communication skills. It is worth noting that the number of female engineering students enrolled in the course over the last 6 years has normally been above the admission percentage of $20 \%$, and in the last offering of the course, 
the ratio of men to women was 1:1.

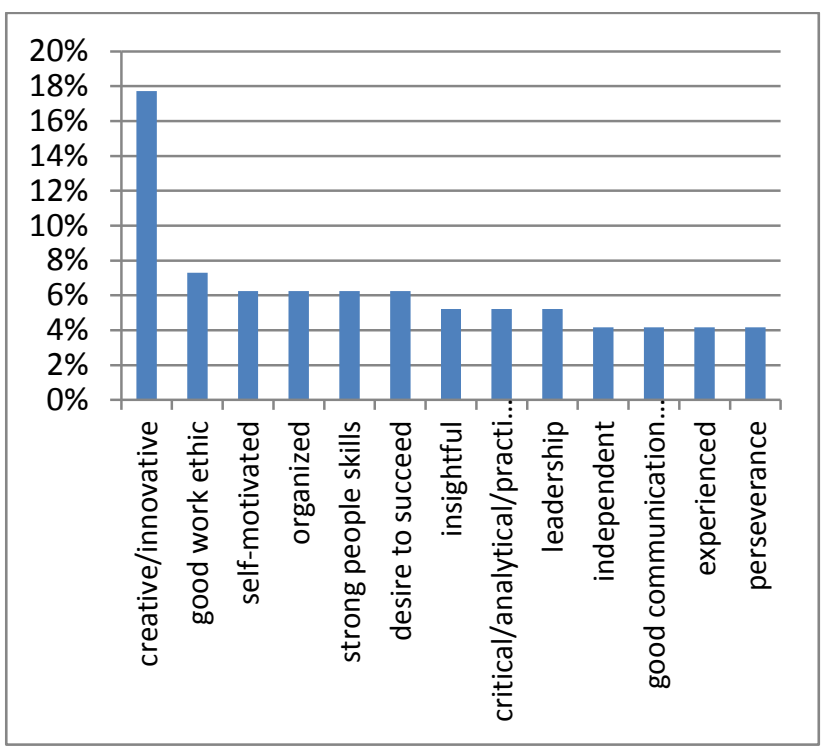

Fig. 7. The entrepreneurial traits observed by Engineering Entrepreneurship students

\section{CONCLUSION}

It is important for engineering students to establish a foundation of lifelong learning, an interest in the impact of engineering on society, ethical decisions, and the environment, professionalism, keen communication skills, and an awareness of the role of innovation in the economy. By studying entrepreneurship, engineering students can start to build these attributes, as well as gain experience in working through the complex business processes that are related to launching a new venture.

Entrepreneurial qualities match engineering personalities, in the sense that both seek the practical application of science to making "everyday life" easier and better. An entrepreneurial mentality adds to the critical thinking skills of an engineer, but also instills a way of thinking that is opportunistic, creative, capable of taking calculated risks, and adaptable to uncertainty.
Passion for the business, product and customer focus, tenacity despite failure, and execution intelligence are key characteristics of the engineer-entrepreneur [7]. In the work that is presented here, developing entrepreneurially minded engineering students include focusing on what identifying opportunities means, understanding what marketing means, completing a business feasibility study, and using peer feedback as a management and networking tool.

\section{References}

[1] Engineers Canada, 2011 Canadian Engineering Accreditation Board: Accreditation Criteria and Procedures Report, http://www.engineerscanada.ca [Retrieved October 3, 2012].

[2] Jim Barnes, Build Your Customer Strategy: A Guide to Creating Profitable Customer Relationships. Hoboken, New Jersey: John Wiley \& Sons, 2006, 202 pp.

[3] Ansoff, I. "Strategies for Diversification", Harvard Business Review, Vol. 35 (5), 1957, pp. 113-124.

[4] Allen, Kathleen. Entrepreneurship for Scientists and Engineers. Upper Saddle River, NJ: Pearson-Prentice Hall, 2010, p 1, 3.

[5] Jay, L. and Schaper, M. "Which Advisers Do Micro-Firms Use? Some Australian Evidence," Journal of Small Business \& Enterprise, 10(2), 2003, 136-143.

[6] Birley, S. and Westhead, P. "A Comparison of New Businesses Established by 'Novice' and 'Habitual' Founders in Great Britain," International Small Business Journal, 12(1), 1993, 38-60.

[7] Barringer, Bruce R. and Ireland, R. Duane. Entrepreneurship: Successfully Launching New Ventures, $4^{\text {th }}$ Edition, Boston, MA: Prentice Hall, 2012. 